\title{
A Relação Estado/Município na Passagem da 4⿳⺈ para a 5 a Série em Curitiba
}

\author{
Autora: Aparecida Reis Barbosa \\ Nível: Mestrado (PPGE/UFPR) \\ Orientador: Prof. Dr. Ângelo Ricardo de Souza
}

\begin{abstract}
O presente trabalho tem como objeto de estudo a relação Estado/Município na passagem da $4^{a}$ para a $5^{a}$ série do ensino fundamental em Curitiba. Compreende-se que o modelo de municipalização das séries iniciais e estadualização das séries finais desenvolvido no Paraná é permeado pela lógica financeiroadministrativa e aprofundado na década de 1990, sob a justificativa da modernização dos processos de gestão, racionalização, eficiência e eficácia, presentes na reforma gerencial do Estado brasileiro e respaldado pelo modelo de federalismo, que se configura com a promulgação da Constituição Federal de 1988 e o regime de colaboração explicitado na Lei n. ${ }^{\circ}$ 9.394/96. No Paraná a particularidade do modelo de municipalização se constitui em uma política de Estado, desde a década de 1970. Destaca-se a participação direta do município de Curitiba na construção desse modelo, com a municipalização de $1^{a}$ a $4^{a}$ série e estadualização da $5^{a}$ a $8^{a}$ série, indicando a necessidade da construção de políticas educacionais articuladoras na passagem da $4^{a}$ para a $5^{a}$ série. A análise aponta para a contradição existente na política nacional
\end{abstract}

\begin{abstract}
de municipalização do ensino, remetendo para o local a efetivação da única etapa da educação básica que tem caráter universal e obrigatório. Os dados empíricos revelam uma crescente precarização da oferta do ensino fundamental em Curitiba, com déficit de vagas em determinadas regiões da cidade. Indica, ainda, que esse modelo de municipalização cria duas redes distintas, articuladas apenas por critérios técnicos e com medidas de enfrentamento unilaterais, longe de dar ao ensino fundamental uma unidade como sistema. Por isso, as alternativas acabam por expressar um caráter localista, fragmentado e unilateral. O esforço empreendido neste estudo foi o de compreender a relação Estado/ Município na passagem da $4^{a}$ para a $5^{a}$ série em Curitiba, para além da aparência, apontando as determinações históricas, sociais e situando algumas contradições do modelo colaborativo, que se materializa no binômio municipalização/ estadualização do ensino fundamental. Nessa perspectiva, buscou-se apontar limites, mas também as possibilidades de superação do que está posto como pronto e acabado, no que se refere ao regime colaborativo.
\end{abstract}

